\title{
Callus Induction, Proliferation, and Plantlets Regeneration of Two Bread Wheat (Triticum aestivum L.) Genotypes under Saline and Heat Stress Conditions
}

\author{
Laid Benderradji, ${ }^{1}$ Faiçal Brini, ${ }^{2}$ Kamel Kellou, ${ }^{1}$ Nadia Ykhlef, ${ }^{1}$ \\ Abdelhamid Djekoun, ${ }^{1}$ Khaled Masmoudi, ${ }^{2}$ and Hamenna Bouzerzour ${ }^{3}$ \\ ${ }^{1}$ Genetic, Biochemistry \& Plant Biotechnology Laboratory, Constantine University, Constantine 25000, Algeria \\ ${ }^{2}$ Plant Protection \& Improvement Laboratory, Centre of Biotechnology of Sfax, University of Sfax, 3018 Sfax, Tunisia \\ ${ }^{3}$ Biology Department, Faculty of Sciences, Sétif University, Sétif 19000, Algeria
}

Correspondence should be addressed to Faiçal Brini, faical.brini@cbs.rnrt.tn

Received 22 August 2011; Accepted 21 September 2011

Academic Editors: W. J. Rogers and Z. Yanqun

Copyright (C) 2012 Laid Benderradji et al. This is an open access article distributed under the Creative Commons Attribution License, which permits unrestricted use, distribution, and reproduction in any medium, provided the original work is properly cited.

\begin{abstract}
Response of two genotypes of bread wheat (Triticum aestivum), Mahon-Demias (MD) and Hidhab (HD1220), to mature embryo culture, callus production, and in vitro salt and heat tolerance was evaluated. For assessment of genotypes to salt and heat tolerance, growing morphogenic calli were exposed to different concentrations of $\mathrm{NaCl}\left(0,5,10\right.$, and $\left.15 \mathrm{~g} \cdot \mathrm{L}^{-1}\right)$ and under different thermal stress intensities $\left(25,30,35\right.$, and $\left.40^{\circ} \mathrm{C}\right)$. Comparison of the two genotypes was reported for callus induction efficiency from mature embryo. While, for salt and heat tolerance, the proliferation efficiency, embryonic efficiency, and regeneration efficiency were used. The results show significant medium and genotype effects for the embryogenesis capacity of calluses induction and plantlets regeneration under saline and thermal stresses. Mahon-Demias showed good callus induction and ability to proliferate and regenerate seedling under heat and salt stress conditions compared to Hidhab. No sizeable differences were observed between the two genotypes at higher salt stress rates. This study will serve as a base line for in vitro screening of several elite wheat cultivars for their ability to induce callus and regenerate plants from mature embryos, and to start selection for tolerance to salinity.
\end{abstract}

\section{Introduction}

Plant tissue culture plays an important role in the production of agricultural and ornamental plants and in the manipulation of plants for improved agronomic performance. In vitro culture of plant cells and tissue has attracted considerable interest over recent years because it provides the means to study plant physiological and genetic processes in addition to offering the potential to assist in the breeding of improved cultivars by increasing genetic variability [1]. In wheat species, different explant sources have been used for embryogenic callus formation and plant regeneration: mature and immature embryos $[2,3]$, infloroscences $[4,5]$, coleoptile [5], shoot apical meristems [6], and anthers [7]. These tissues vary in their ability to regenerate whole plants [8]. Immature embryos and immature infloroscences gave the highest frequencies of regenerated plants in vitro [5]. Tissue culture responses which include callus induction and regeneration capacity of wheat are influenced by the genotypes, explant source, geographical origin and physiological status of the donor plants, the culture medium, and the interactions between them [3]. Both mature and immature embryos have been used extensively in tissue culture protocols, but mature embryos were found to be a better choice in comparison to immature embryos [2]. Immature embryos are better explant source when regeneration is considered, but they require time and growth facilities [9] whereas mature embryos are available throughout the year. Mature embryos can either be dissected [10] or used directly [2].

Media composition-mainly the hormonal balance-is an important factor influencing in vitro culture initiation and plant regeneration from embryos [11]. The auxin 2, 
4-dichlorophenoxy acetic acid (2, 4-D) alone or in combination with cytokinins, is widely used to enhance callus induction and maintenance [12]. Genetic factors are considered to be a major contributor to the in vitro response of cultured tissues. Differences in the production of embryogenic calli and the regenerated plantlets have been observed, depending on the genotype and source of the explants [13].

Plant response to abiotic stress is a complex phenomenon, which could be approached efficiently through in vitro culture. Tolerant lines derived from conventional breeding programs or resulting from transgenic transformations could be screened via in vitro culture. This is particularly attractive for certain abiotic stresses where appropriate screening methods are unavailable or not efficient. Plant tissue culture techniques provide a promising and feasible approach to develop salt tolerant plants. In vitro selection of salt tolerant cell lines has been reported for several species (for review see $[14,15]$ ). Although research has been conducted on in vitro selection for salt tolerance in wheat utilizing mainly somaclonal variants $[16,17]$, limited studies have been undertaken to the genotypic potential assessment for both callus induction and in vitro salt tolerance. Salinity is the main abiotic stress that has been addressed by in vitro selection, but applications to other stresses such as heat and drought have been reported [18]. High temperature has detrimental effects on plant growth and development, such as tassel initiation and time of flowering [19], pollen sterility [20], and rate and duration of endosperm cell division [21]. High temperature induced oxidative stress in plants [22], which caused lipid peroxidation and consequently membrane injury, protein degradation, enzyme inactivation, pigment bleaching and disruption of DNA strands [23, 24]. In addition, this is the major factor influencing the embryogenic response and plant regeneration. The combined effect of temperature incubation and medium composition on the regeneration frequency of calli derived from wheat immature embryos was reported by Creus et al. [25].

The present work was, therefore, performed in order to gain information on the comparative effects of salt and heat stress on cell viability, cell growth, and cellular recovering abilities using callus obtained from two cultivars (cvs.) of Triticum aestivum exhibiting contrasting levels of salinity and heat resistance, Mahon-Demias (MD) and Hidhab (HD1220).

\section{Material and Methods}

2.1. Plant Materials. The seeds of two bread wheat cultivars Triticum aestivum L. Mahon-Demias (MD, salt sensitive) and Triticum aestivum L. Hidhab (HD1220, salt tolerant) were supplied by the Agricultural Research Station of the Technical Institute of Field Crops (ARS-ITGC) of Setif, Algeria and used as explants.

2.2. Callus Induction. Seeds of each line were sterilized in $0.5 \% \mathrm{NaOCl}$ for $15 \mathrm{~min}$, and then washed three times with sterile water. After disinfection, the mature embryos were extracted from seeds, under laminar flow hood; using a sterilized metallic scalpel and placed, scutelum side up, in Petri dishes containing Murashigue and Skoog culture medium [26], supplemented with $30 \mathrm{~g} \cdot \mathrm{L}^{-1}$ saccharose, $8 \mathrm{~g} \cdot \mathrm{L}^{-1}$ agar, and $10 \mathrm{mg} \cdot \mathrm{L}^{-1} \quad 2,4-\mathrm{D}$, for callus induction. Petri dishes were sealed with polyethylene film and were placed in a growth culture room under a photoperiod of $16 \mathrm{~h}$ light $/ 8 \mathrm{~h}$ darkness, at temperature varied between 22 and $25^{\circ} \mathrm{C}$, under $280 \mathrm{mmol} \cdot \mathrm{m}^{2} \cdot \mathrm{s}^{-1}$ light intensity. Eight mature embryos were plated per Petri dish, for a total of 96 embryos tested per genotype.

2.3. In Vitro Salt and Heat Treatment. After four weeks of incubation, the induced calli were separately subcultured in MS medium supplemented with various $\mathrm{NaCl}$ concentrations $\left(0,5,10\right.$, and $\left.15 \mathrm{~g} \cdot \mathrm{L}^{-1}\right)$, and under different thermal stress intensities $\left(25,30,35\right.$, and $\left.40^{\circ} \mathrm{C}\right)$, during 3 hours. The transplant was performed 4 weeks after in glass tubes culture on MS $+30 \mathrm{~g} \cdot \mathrm{L}^{-1}$ of sucrose, $8 \mathrm{~g} \cdot \mathrm{L}^{-1}$ of agar, $2 \mathrm{mg} \cdot \mathrm{L}^{-1}$ of $\mathrm{BAP}$, and $0.5 \mathrm{mg} \cdot \mathrm{L}^{-1} \mathrm{NAA}$, for shoot regeneration.

2.4. Plant Regeneration. Regenerated explants were placed in a growth medium containing half strength MS medium (MS/2), solidified with $8 \mathrm{~g} \cdot \mathrm{L}^{-1}$ of agar and supplemented with $30 \mathrm{~g} \cdot \mathrm{L}^{-1}$ of sucrose, $0.8 \mathrm{mg} \cdot \mathrm{L}^{-1} \mathrm{NAA}$, and $0.36 \mathrm{mg} \cdot \mathrm{L}^{-1}$ Kinetin for root regeneration (Table 1). The flaks were placed in the culture room under fluorescent light at ambient temperature of $22^{\circ} \mathrm{C}$. The medium is changed every 15-day period. At the end of this period, callus with clearly differentiated shoots and roots was scored as regenerating callus. Each piece of regenerating callus was counted as one regardless of the number of shoots and roots. The regenerating calli, showing shoot and root formations, were transferred onto MS basal medium without growth regulators and placed in a lighted chamber to sustain the regenerated plantlets growth. The data were obtained on callus induction efficiency measured as the number of calli/total number of embryos tested $\times 100$; the embryogenesis efficiency measured as the number of calli forming shoots/total number of calli $\times 100$; the regeneration efficiency measured as the number of plantlets/total number of calli $\times 100$. The number of leaves and roots per plantlet and the maximum root length were scored and callus areas were also determined.

2.5. Statistical Analysis. Data interpretation effect of different salt concentration and heat degrees used is performed by analysis of variance using the software "STATITCF" version 4 , followed by a comparison of means test at $5 \%$ level fisher. The separation of homologeneous groups observed among several medium is made according the Newman-Keuls test at $5 \%$ levels.

\section{Results and Discussion}

\subsection{Genotypic Capacity of Callus Induction}

3.1.1. Salt Stress Effect. Callus induction rate and regeneration capacity of callus were greatly influenced by the genotype. Data analysis showed a callus induction rate of 
TABLE 1: MS media used: calogenesis (MS1), caulogenesis (MS2), and rhizogenesis (MS3).

\begin{tabular}{lccc}
\hline Medium & $\begin{array}{c}\text { MS1 }= \\
\text { Calogenesis }\end{array}$ & $\begin{array}{c}\text { MS2 }= \\
\text { Caulogenesis }\end{array}$ & $\begin{array}{c}\text { MS3 }= \\
\text { Rhizogenesis }\end{array}$ \\
\hline Macroelements & MS & MS & MS/2 \\
Microelements & & MS & \\
Vitamins & & MS & \\
Fe-EDTA & & MS & \\
Saccharose $\left(\mathrm{g} \cdot \mathrm{L}^{-1}\right)$ & & 30 & \\
Agar $\left(\mathrm{g} \cdot \mathrm{L}^{-1}\right)$ & 10 & - & - \\
\hline 2.4 D $\left(\mathrm{mg} \cdot \mathrm{L}^{-1}\right)$ & - & 2 & - \\
BAP $\left(\mathrm{mg} \cdot \mathrm{L}^{-1}\right)$ & - & 0.5 & 0.8 \\
ANA $\left(\mathrm{mg} \cdot \mathrm{L}^{-1}\right)$ & - & - & 0.36 \\
KIN $\left(\mathrm{mg} \cdot \mathrm{L}^{-1}\right)$ & & 5.8 & \\
\hline pH & &
\end{tabular}

$88.5 \%$ and $58.3 \%$, respectively for Mahon-Demias (MD) and Hidhab (HD) cultivars, suggesting significant genotypic differences in the callus induction capacity between the two genotypes (Table 2). These results corroborate those of He et al. [27], Gonzalez et al. [28], Rashid et al. [29], Chen et al. [30], and Nasircilar et al. [31] whom reported variation in callus induction and seedling regeneration frequencies varying from 11.6 to $100.0 \%$ in durum and bread wheat. According to these authors, several factors such as medium composition, nature of genotype, and explants used are sources of variation affecting processes relating to the capacity of callus induction, embryonic differentiation, and plantlets regeneration. Özgen et al. [3] compared the efficiency of mature against immature embryos; he mentioned that mature embryos showed low callus induction frequency, compensated by higher plantlets regeneration of plantlets. In this study, the variation noted for the capacity of callus induction is related to genotypic effect. The effect of salinity on callus area was superior on HD genotype compared to the other genotype MD (Figure 1). Under saline conditions, MD supported moderate salt stress intensity and behaved as a more tolerant cultivar than HD (Figure 1). These results were in agreement with those reported for barley [32]. The finding of superior genotype "MD" compared to HD for salt tolerance at cellular level together with its high potential for callus induction leads us to the conclusion that a hybridization breeding procedure using this superior plant materials supplemented with in vitro selection for salt tolerance might be beneficial for improving this trait in bread wheat.

3.1.2. Heat Stress Effect. Both varieties were significantly affected by heat stress, but compared to $\mathrm{HD}, \mathrm{MD}$ was relatively more tolerant to heat stress treatments, as far as callus induction is concerned (Table 3 ). The same result was observed for callus area, for which HD exhibited a linear decrease in response to heat stress, while MD was less responsive to heat treatment change (Figure 2). These findings agree with those of Dani [33] who found that callus

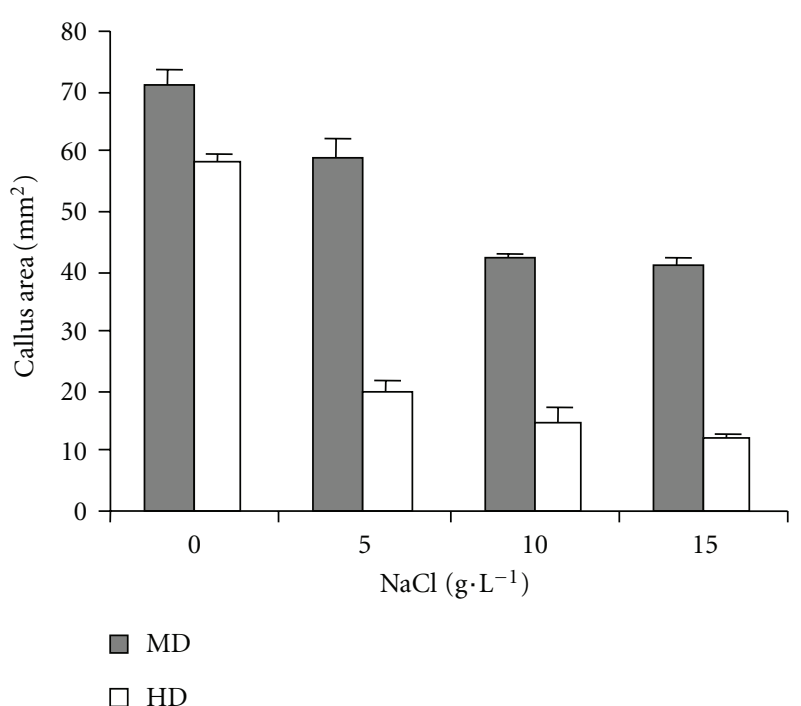

Figure 1: Salt stress effect on callus area of MD and HD genotypes.

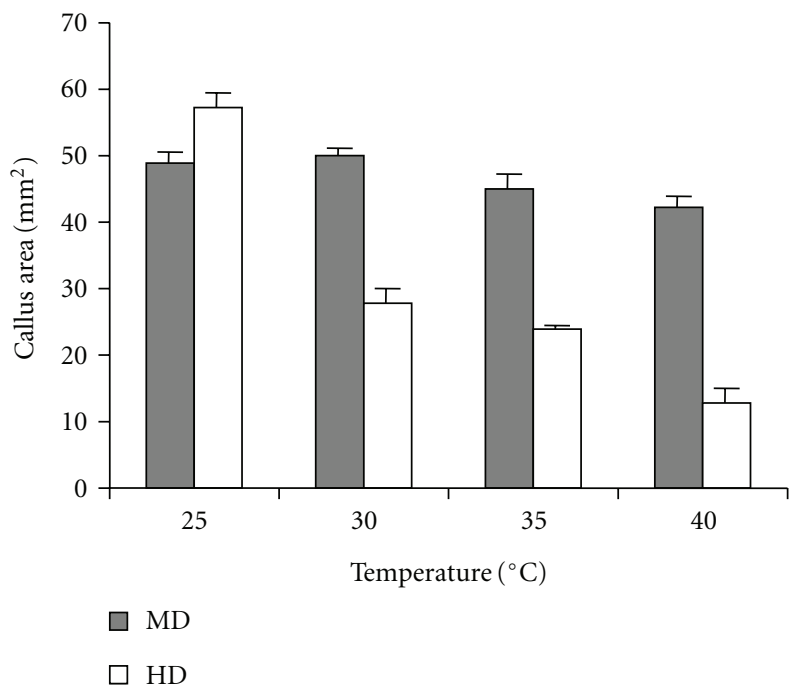

FIGURE 2: Heat stress effects on callus area of MD and HD genotypes.

biomass production is reduced on exposure to high temperatures for longer periods in cotton. HD was earlier found to be severely affected by high temperature. Degree of heat tolerance observed in the whole plant in HD was exhibited in callus tissues also. These results suggest a heat tolerance mechanism operating at cellular as well as whole plant level.

3.2. Callus Proliferation and Plantlets Regeneration under Salt Stress. Callus proliferation efficiency differed significantly between genotypes, varied according to the salt treatments tested (Table 2, Figure 3). MD showed more tolerance to salt stress $\left(5 \mathrm{~g} \cdot \mathrm{L}^{-1} \mathrm{NaCl}\right)$ compared to HD. At higher levels of salt stress, MD reacts moderately whereas HD showed abrupt decrease in the capacity of callus proliferation which reached $25 \%$ at $15 \mathrm{~g} \cdot \mathrm{L}^{-1} \mathrm{NaCl}$ treatments (Table 2). MD presented 
TABLE 2: Genotypes mean values of the measured variables at different salt treatments.

\begin{tabular}{|c|c|c|c|c|c|c|c|c|}
\hline \multicolumn{9}{|c|}{ Genotypic callus induction efficiency } \\
\hline Genotype & \multicolumn{4}{|c|}{$\mathrm{MD}$} & \multicolumn{4}{|c|}{$\mathrm{HD}$} \\
\hline No. incubated embryos & \multicolumn{4}{|c|}{96.0} & \multicolumn{4}{|c|}{96.0} \\
\hline No. of calli embryos & \multicolumn{4}{|c|}{85.0} & \multicolumn{4}{|c|}{56.0} \\
\hline Efficiency of calli induction (\%) & \multicolumn{4}{|c|}{88.5} & \multicolumn{4}{|c|}{58.3} \\
\hline \multicolumn{9}{|c|}{ Effect of saline stress $(\mathrm{NaCl})$} \\
\hline Genotype & \multicolumn{4}{|c|}{$\mathrm{MD}$} & \multicolumn{4}{|c|}{ HD } \\
\hline $\mathrm{NaCl}\left(\mathrm{g} \cdot \mathrm{L}^{-1}\right)$ & 0 & 5 & 10 & 15 & 0 & 5 & 10 & 15 \\
\hline No. of incubated embryos & 24,0 & 24,0 & 24,0 & 24,0 & 24,0 & 24,0 & 24,0 & 24,0 \\
\hline No. Proliferating calli & 24,0 & 24,0 & 21,0 & 15,0 & 22,0 & 20,0 & 08,0 & 06,0 \\
\hline Proliferation efficiency (\%) & 100,0 & 100,0 & 91.6 & 62.5 & 91.6 & 83.3 & 33.3 & 25.0 \\
\hline No. cal with 2 shoots & 02,0 & 02,0 & 01,0 & 00,0 & 05,0 & 03,0 & 01,0 & 00,0 \\
\hline Embryonic efficiency (\%) & 08.3 & 08.3 & 04.2 & 00.0 & 20.8 & 12.5 & 04.2 & 00.0 \\
\hline No. cal with 1 root & 01,0 & 01,0 & 00,0 & 00,0 & 01,0 & 00,0 & 00,0 & 00,0 \\
\hline No. of regenerating calli & 01,0 & 01,0 & 00,0 & 00,0 & 01,0 & 00,0 & 00,0 & 00,0 \\
\hline Regeneration efficiency (\%) & 04.2 & 04.2 & 00.0 & 00.0 & 04.2 & 00.0 & 00.0 & 00.0 \\
\hline No. sheets/plantlet & 04,0 & 03,0 & 00,0 & 00,0 & 02,0 & 00,0 & 00,0 & 00,0 \\
\hline No. roots/plantlet & 02,0 & 02,0 & 00,0 & 00,0 & 02,0 & 00,0 & 00,0 & 00,0 \\
\hline No. root length (mm) & 25,0 & 20,0 & 00,0 & 00,0 & 20,0 & 00,0 & 00,0 & 00,0 \\
\hline
\end{tabular}

TABLE 3: Genotypes mean values of the measured variables at different heat treatments.

\begin{tabular}{|c|c|c|c|c|c|c|c|c|}
\hline \multicolumn{9}{|c|}{ Genotypic callus induction efficiency } \\
\hline Genotype & \multicolumn{4}{|c|}{$\mathrm{MD}$} & \multicolumn{4}{|c|}{ HD } \\
\hline No. incubated embryos & \multicolumn{4}{|c|}{96.0} & \multicolumn{4}{|c|}{96.0} \\
\hline No. embryos showing calli & \multicolumn{4}{|c|}{45.0} & \multicolumn{4}{|c|}{35.0} \\
\hline Callus efficiency $(\%)$ & \multicolumn{4}{|c|}{46.8} & \multicolumn{4}{|c|}{36.4} \\
\hline \multicolumn{9}{|c|}{ Effect of heat stress $\left({ }^{\circ} \mathrm{C}\right)$} \\
\hline Genotype & \multicolumn{4}{|c|}{$\mathrm{MD}$} & \multicolumn{4}{|c|}{ HD } \\
\hline Heat $\left({ }^{\circ} \mathrm{C}\right)$ & 25 & 30 & 35 & 40 & 25 & 30 & 35 & 40 \\
\hline No. of incubated embryos & 24 & 24 & 24 & 24 & 24 & 24 & 24 & 24 \\
\hline No. proliferating calli & 15 & 12 & 10 & 08 & 12 & 10 & 08 & 05 \\
\hline Proliferation efficiency (\%) & 62.5 & 50.0 & 41.6 & 33.3 & 50.0 & 41.6 & 33.3 & 20.8 \\
\hline No. calli differentiating shoot & 2.0 & 2.0 & 1.0 & 0.0 & 5.0 & 3.0 & 1.0 & 0.0 \\
\hline Embryogenic efficiency (\%) & 13.3 & 16.6 & 10.0 & 0.0 & 41.6 & 30.0 & 12.0 & 0.0 \\
\hline No. calli differentiating root & 1.0 & 0.0 & 0.0 & 0.0 & 1.0 & 0.0 & 0.0 & 0.0 \\
\hline No. regenerating calli & 1.0 & 1.0 & 0.0 & 0.0 & 1.0 & 0.0 & 0.0 & 0.0 \\
\hline Regeneration efficiency (\%) & 4.1 & 4.1 & 0.0 & 0.0 & 4.1 & 0.0 & 0.0 & 0.0 \\
\hline No. leaves/plantlet & 4.0 & 3.0 & 0.0 & 0.0 & 2.0 & 0.0 & 0.0 & 0.0 \\
\hline No. roots/plantlet & 2.0 & 2.0 & 0.0 & 0.0 & 2.0 & 0.0 & 0.0 & 0.0 \\
\hline Root length (mm) & 25.0 & 20.0 & 0.0 & 0.0 & 20.0 & 0.0 & 0.0 & 0.0 \\
\hline
\end{tabular}

TABLE 4: Plantlets regeneration per calli after exposure to both saline and thermal stresses.

\begin{tabular}{|c|c|c|c|c|c|c|c|c|}
\hline & \multicolumn{4}{|c|}{$\mathrm{NaCl}\left(\mathrm{g} \cdot \mathrm{L}^{-1}\right)$} & \multicolumn{4}{|c|}{ Temperature $\left({ }^{\circ} \mathrm{C}\right)$} \\
\hline & 0 & 5 & 10 & 15 & 25 & 30 & 35 & 40 \\
\hline No. of morphogenesis calli (HD) & 01 & 00 & 00 & 00 & 01 & 00 & 00 & 00 \\
\hline No. of morphogenesis calli (MD) & 01 & 01 & 00 & 00 & 01 & 01 & 00 & 00 \\
\hline (HD) MNPR & & \multicolumn{2}{|c|}{01.00} & & \multicolumn{2}{|c|}{01.00} & & \\
\hline (MD) MNPR & & \multicolumn{2}{|c|}{02.00} & & \multicolumn{2}{|c|}{02.00} & & \\
\hline$\% \mathrm{HD}$ regenerated plantlets & & \multicolumn{2}{|c|}{01.78} & & \multicolumn{2}{|c|}{01.78} & & \\
\hline$\%$ MD regenerated plantlets & & \multicolumn{2}{|c|}{02.43} & & \multicolumn{2}{|c|}{02.27} & & \\
\hline
\end{tabular}




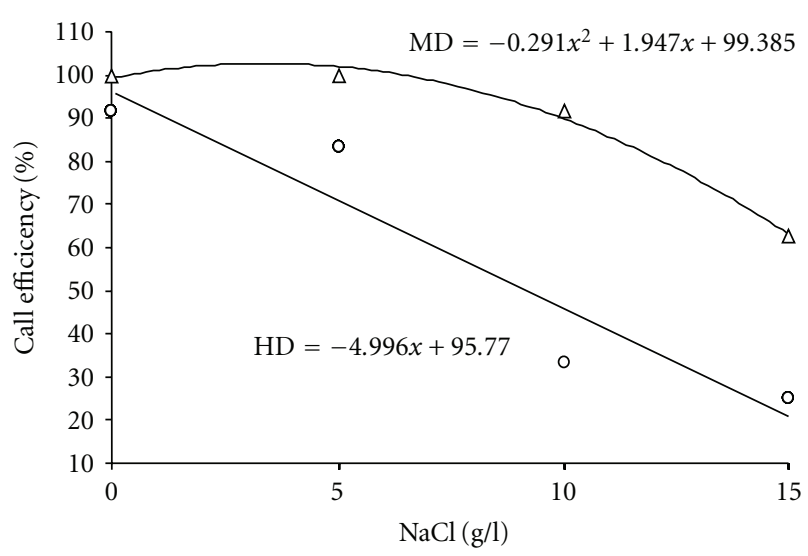

$\triangle \mathrm{MD}$

O HD

Figure 3: $\mathrm{NaCl}$ effect on callus proliferation efficiency of MD and HD genotypes.

a curvilinear-type response to salinity whereas HD exhibited a linear response type (Figure 3). 2.4-D is generally reported as the best auxine which supports and enhances callus induction and subculture of grasses [34]. In the present study, 2.4$\mathrm{D}$ auxin was used at a concentration of $10 \mathrm{mg} \cdot \mathrm{L}^{-1}$ of $\mathrm{MS}$ medium for callus proliferation. The results indicated that there were genotypic differences in callus proliferation under saline conditions. MD, a landrace-variety, exhibited tolerance to salt stress compared to the recently released variety HD. However, on moderate salinity levels, MD showed a low embryonic efficiency with a value of $8.3 \%$, while HD exhibited a relatively higher value of $12.5 \%$ for the same trait. The difference between the two genotypes for this characteristic is not significant at higher levels of salinity (Table 2, Figure 4). According to Bradle et al. [35], addition of cytokinins to the culture medium, particularly BAP at low concentration, enhances the formation of embryonic calli. Here, MS medium was supplemented with $2 \mathrm{mg} \cdot \mathrm{L}^{-1} \mathrm{BAP}$ and $0.5 \mathrm{mg} \cdot \mathrm{L}^{-1} \mathrm{NAA}$ for shoot initiation; and with $0.8 \mathrm{mg} \cdot \mathrm{L}^{-1}$ NAA and $0.36 \mathrm{mg} \cdot \mathrm{L}^{-1}$ Kinetin for root formation.

The regeneration rate of seedlings was null under salinity for $\mathrm{HD}$ proliferating calli and very low, taking a value of $4 \%$ for MD. He et al. [36] mentioned that IAA supports production of an excessive radicular system. Bregitzer et al. [37] report that the number of green plantlets produced by incubated embryos was significantly affected by genotype and 2.4-D auxin concentration. Balli et al. [38] reported a maximum regeneration rate with the addition of $2.5 \mathrm{mg} \cdot \mathrm{L}^{-1}$ of 2.4-D. Neither the IAA nor the 2.4-D was used for the regeneration of the plantlets in the present study. Generally, cellular cultures of high totipotency result from the friable embryogenic calli. Here, the majority of explants take the brownish color under salinity, well before the formation of tiller. Friable embryogenic calli were difficult to obtain from both genotypes. However, calli having green tasks developed quickly tillers and an average of 2 roots per plantlet, in the initial medium. The shoots developed slowly, producing 2- to 4- rolled up leaves. However, when seedlings were placed in the roots regeneration medium, roots and shoots growth was faster. The initiated roots had length varying from 20 to $25 \mathrm{~mm}$ (Table 2).

3.3. Main Number Plantlets Regenerated (MNPR). Plantlets regenerated from the two tested varieties were determinate as mean number of plantlets regenerated per number of calli proliferated per variety. We noted that the number of plantlets regenerated for both tested genotypes was low under salt as well as under heat stress (Table 4, Figure 5). El-Meleigy et al. [39] reported that $\mathrm{NaCl}$ inhibited tomato plantlets regeneration. Rus et al. [40] found a positive correlation between the response to the salinity of cells resulting from the calli proliferation and that of adult plants. Rus et al. [41] noted a reduction of the relative growth rate and relative water content of proliferating calli in salted medium comparatively to proliferating calli-free salt medium. Chen et al. [42] noted that shoots growth of Eucalyptus microcorys was inhibited under salinity. Abebe et al. [43] get a reduction of $37 \%$ of callus growth in saline stress conditions at $100 \mathrm{mM} \mathrm{NaCl}$. Salinity is regarded as being a major factor limiting development of plants and crops production potential. The adult plant performance of $\mathrm{MD}$ and HD cultivars under salt stress revealed two major differences between the two genotypes (i) a lower rate of transfer from the root to the shoot (xylem loading) in the salt tolerant genotype, and (ii) a higher capacity of the leaf sheath in the tolerant genotype to extract and sequester $\mathrm{Na}^{+}$ as it entered the leaf [44]. Lutts et al. [45] reported that in salt conditions, calli obtained from the wheat-resistant genotype exhibited the highest relative growth rate (RGR) and this is in accordance with a lower impact of high $\mathrm{NaCl}$ dose on whole plant growth of this genotype.

Salinity develops more particularly in the arid and semiarid areas. Salinity tolerance is a polygenic trait, difficult to select for using traditional methods under field conditions [46]. In vitro culture is an alternate way to generate salt tolerant plants. Transgenic plant production overexpressing salt tolerance genes can also contribute positively to this objective [46-48]. In vitro culture constitutes a powerful method to improve salinity tolerance via somaclonale variation. It is also a means which contributes to seedling genetic transformation. In this context, it is important to develop an efficient protocol for callus proliferation for the in vitro selection of tolerant plant material against abiotic stresses and to enlarge research toward genetic engineering.

\section{Conclusion}

In vitro tissue culture could be an important means of improving crop tolerance and yield through genetic transformation as well as by induced somaclonal variation. Therefore, it is important to devise an efficient protocol of callus proliferation to start in vitro selection for salt and heat stress tolerance, and to broaden opportunities for genetic manipulation of wheat through tissue culture, including trying various explants and media. The results of this study indicated that MD showed a good callus induction while 


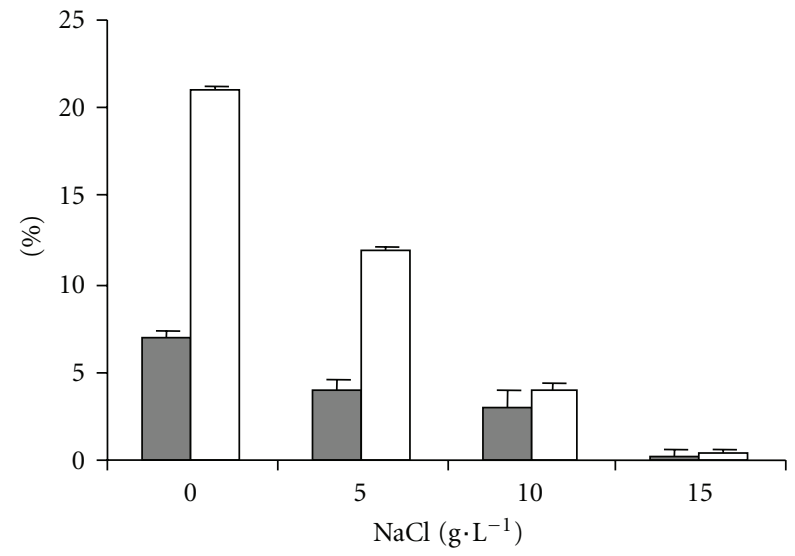

$\square \mathrm{MD}$

$\square \mathrm{HD}$

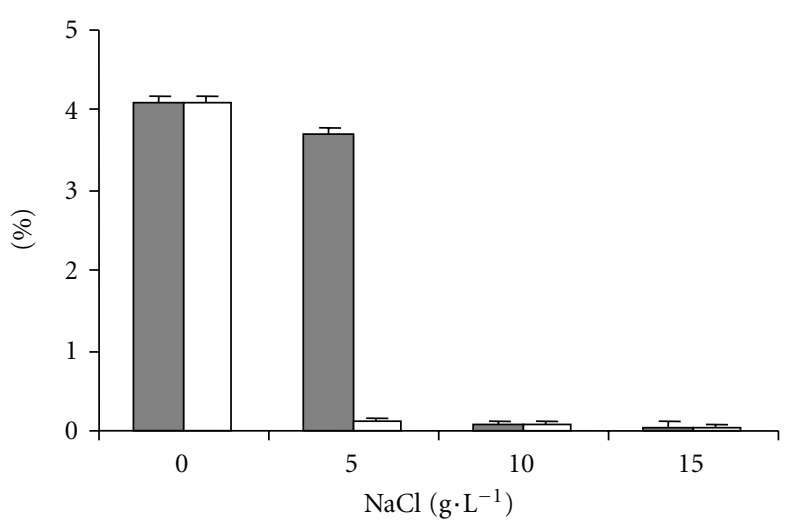

$\square \mathrm{MD}$

$\square \mathrm{HD}$

(a)

(b)

FIGURE 4: Embryogenic (a) and regeneration (b) efficiencies of MD and HD genotypes in response to salt stress.
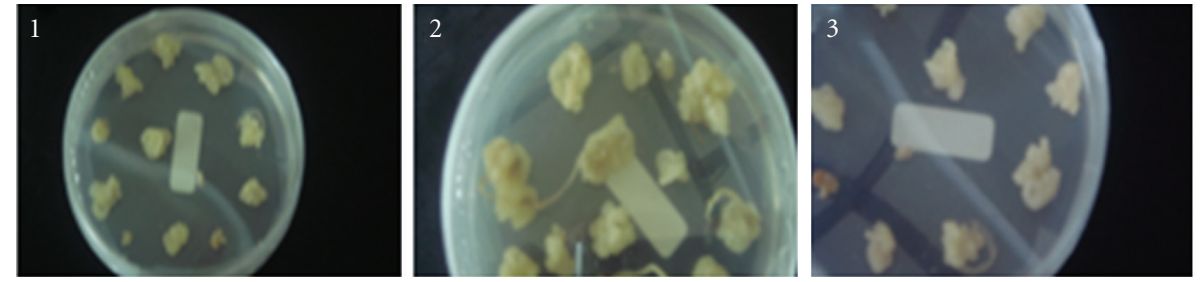

(a)
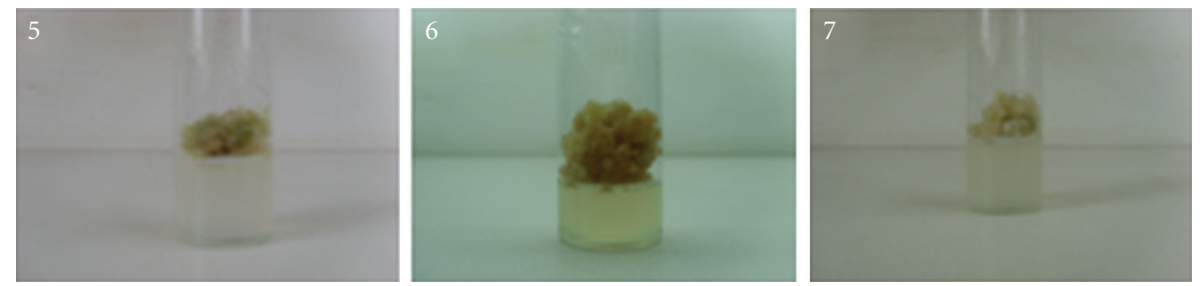

(b)
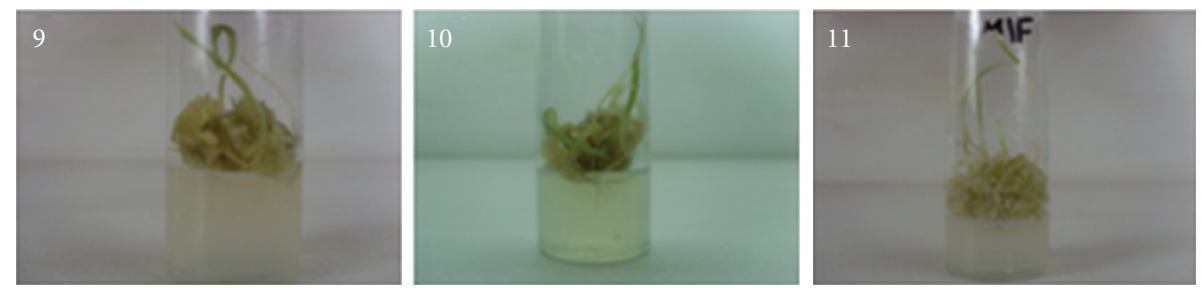

(c)
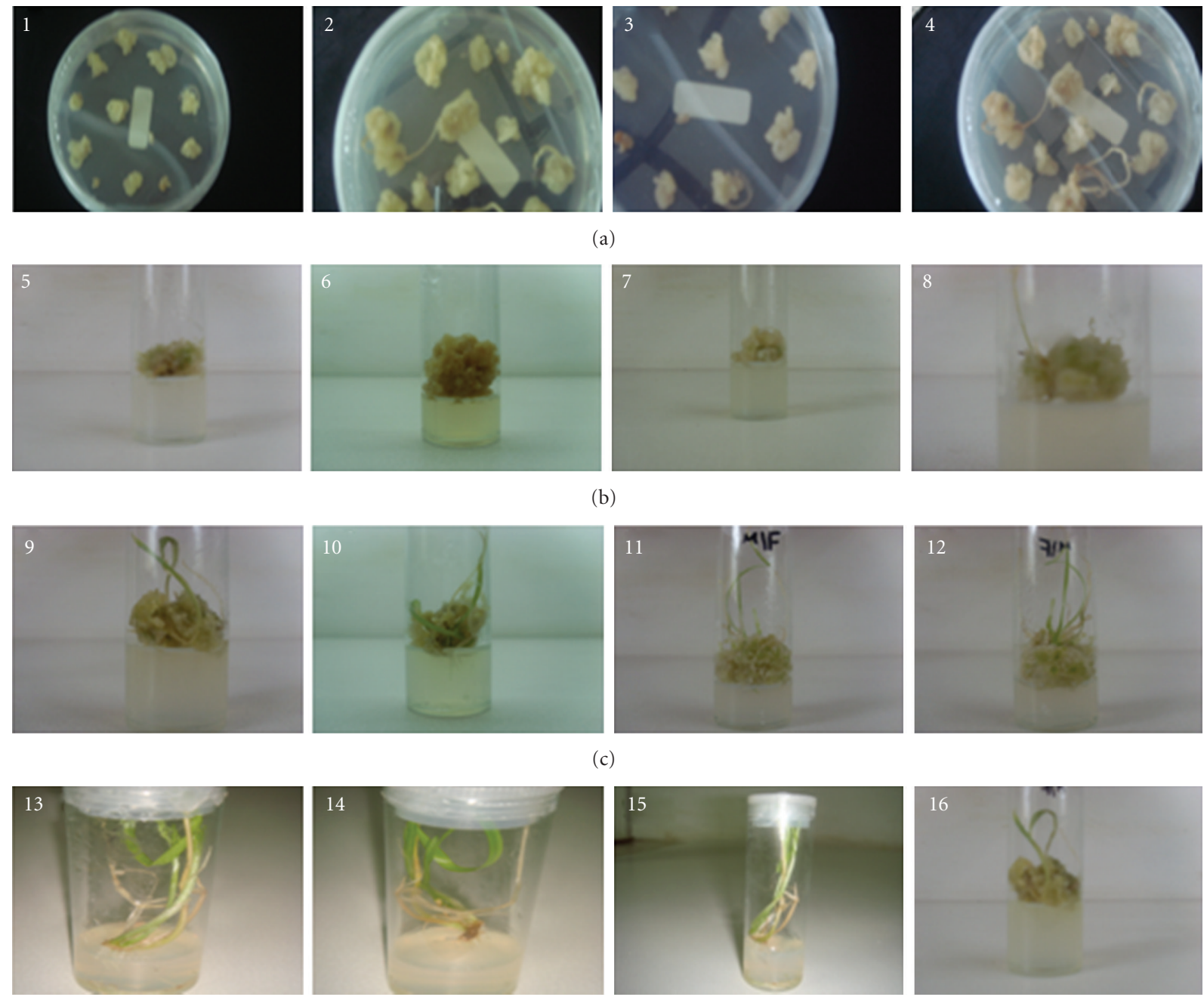

(d)

FIGURE 5: In vitro tissue culture mature embryos photography: (a) cal induction, (b) proliferation, (c) leaves formation, (d) root formation of MD (heat stress: 1, 5, 9, and 13, salt stress: 2, 6, 10 and 14); HD (heat stress: 3, 7, 11, and 15, salt stress: 4, 8, 12, and 16). 
HD exhibited a rather intermediate-to-low callus induction capacity. Differential genotypic response was also noted in callus ability to proliferate and regenerate seedling under heat and salt stress conditions. Therefore, to obtain a suitable wheat plant regeneration system for a given genotype of wheat, it is necessary to screen several elite wheat cultivars for their ability to induce callus and regenerate plants from mature embryos, and to start selection for tolerance to salinity.

\section{Author's Contribution}

L. Benderradji and F. Brini contributed equally to this work and should be considered as cofirst authors.

\section{Acknowledgments}

This work was supported jointly by grants from the Ministry of Higher Education and Scientific Research, Tunisia, and the Ministry of Higher Education and Scientific Research, Algeria.

\section{References}

[1] A. Karp, S. H. Steel, S. Parmar, M. G. K. Jones, P. R. Shewry, and A. Breiman, "Relative stability among barley plants regenerated from cultured immature embryos," Genome, vol. 29, pp. 405-412, 1987.

[2] M. Özgen, M. Türet, S. Altinok, and C. Sancak, "Efficient callus induction and plant regeneration from mature embryo culture of winter wheat (Triticum aestivum L.) genotypes," Plant Cell Reports, vol. 18, no. 3-4, pp. 331-335, 1998.

[3] M. Özgen, M. Türet, S. Özcan, and C. Sancak, "Callus induction and plant regeneration from immature and mature embryos of winter durum wheat genotypes," Plant Breeding, vol. 115, no. 6, pp. 455-458, 1996.

[4] F. A. Redway, V. Vasil, D. Lu, and I. K. Vasil, "Identification of callus types for long-term maintenance and regeneration from commercial cultivars of wheat (Triticum aestivum L.)," Theoretical and Applied Genetics, vol. 79, no. 5, pp. 609-617, 1990.

[5] H. Benkirane, K. Sabounji, A. Chlyah, and H. Chlyah, "Somatic embryogenesis and plant regeneration from fragments of immature inflorescences and coleoptiles of durum wheat," Plant Cell, Tissue and Organ Culture, vol. 61, no. 2, pp. 107-113, 2000.

[6] A. Ahmad, H. Zhong, W. Wang, and M. B. Sticklen, "Shoot apical meristem: in vitro regeneration and morphogenesis in wheat (Triticum aestivum L.)," In Vitro Cellular and Developmental Biology, vol. 38, no. 2, pp. 163-167, 2002.

[7] T. A. Armstrong, S. G. Metz, and P. N. Mascia, "Two regeneration systems for the production of haploid plants from wheat anther culture," Plant Science, vol. 51, no. 2-3, pp. 231-237, 1987.

[8] F. Delporte, O. Mostade, and J. M. Jacquemen, "Plant regeneration through callus initiation from thin mature embryo fragments of wheat (Triticum aestivum) genotypes," Plant Cell, Tissue and Organ Culture, vol. 67, no. 1, pp. 73-80, 2001.

[9] J. M. Zale, H. Borchardt-Wier, K. K. Kidwell, and C. M. Steber, "Callus induction and plant regeneration from mature embryos of a diverse set of wheat genotypes," Plant Cell, Tissue and Organ Culture, vol. 76, no. 3, pp. 277-281, 2004.

[10] Y. Yu, J. Wang, M. L. Zhu, and Z. M. Wei, "Optimization of mature embryo-based high frequency callus induction and plant regeneration from elite wheat cultivars grown in China," Plant Breeding, vol. 127, no. 3, pp. 249-255, 2008.

[11] W. Jiang, C. Myeong-Je, and P. G. Lemaux, "Improved callus quality and prolonged regenerability in model and recalcitrant barley (Hordeum vulgare L.) cultivars," Plant Biotechnology, vol. 15, no. 2, pp. 63-69, 1998.

[12] A. M. Castillo, B. Egaña, J. M. Sanz, and L. Cistué, "Somatic embryogenesis and plant regeneration from barley cultivars grown in Spain," Plant Cell Reports, vol. 17, no. 11, pp. 902906, 1998.

[13] S. Ganeshan, M. Baga, B. L. Harwey, B. G. Rossnagel, G. J. Scoles, and R. N. Chibbar, "Production of multiple s hoots from thiadiazuron-treated mature embryos and leaf-base/ apical meristems of barley (Hordeum vulgare L.)," Plant Cell, Tissue and Organ Culture, vol. 73, pp. 57-64, 2003.

[14] M. Dracup, "Increasing salt tolerance of plants through cell culture requires greater understanding of tolerance mechanisms," Australian Journal of Plant Physiology, vol. 18, pp. 1$15,1991$.

[15] M. Tal, "In vitro selection for salt tolerance in crop plants: theoretical and practical considerations," In Vitro Cellular and Developmental Biology, vol. 30, no. 4, pp. 175-180, 1994.

[16] M. N. Barakat and T. H. Abdel-Latif, "In vitro selection of wheat callus tolerant to high levels of salt and plant regeneration," Euphytica, vol. 91, no. 2, pp. 127-140, 1996.

[17] M. Karadimova and G. Djambova, "Increased NaCl-tolerance in wheat (Triticum aestivum L. and T. durum Desf.) through in vitro selection," In Vitro Cellular and Developmental Biology, vol. 23, pp. 180-182, 1993.

[18] S. Lutts, J. M. Kinet, and J. Bouharmont, "Effects of salt stress on growth, mineral nutrition and proline accumulation in relation to osmotic adjustment in rice (Oryza sativa L.) cultivars differing in salinity resistance," Plant Growth Regulation, vol. 19, no. 3, pp. 207-218, 1996.

[19] R. H. Ellis, R. J. Summerfield, G. O. Edmeades, and R. H. Roberts, "Photoperiod, temperature, and the interval from sowing to tassel initiation in diverse cultivars of maize," Crop Science, vol. 32, pp. 1225-1232, 1992.

[20] H. S. Saini and D. Aspinall, "Sterility in wheat (Triticum aestivum L.) induced by water deficit or high temperature: possible mediation by abscisic acid," Australian Journal of Plant Physiology, vol. 9, pp. 529-537, 1982.

[21] R. J. Jones, J. A. Roessler, and S. Ouattar, "Thermal environment during endosperm cell division in maize: effect on number of endosperm cells and starch granules," Crop Science, vol. 25, pp. 830-834, 1985.

[22] M. Gong, S. N. Chen, Y. Q. Song, and Z. G. Li, "Effect of calcium and calmodulin on intrinsic heat tolerance in relation to antioxidant systems in maize seedlings," Australian Journal of Plant Physiology, vol. 24, no. 3, pp. 371-379, 1997.

[23] J. A. Anderson and S. R. Padhye, "Protein aggregation, radical scavenging capacity, and stability of hydrogen peroxide defense systems in heat-stressed vinca and sweet pea leaves," Journal of the American Society for Horticultural Science, vol. 129, no. 1, pp. 54-59, 2004.

[24] J. A. Imlay and S. Linn, "DNA damage and oxygen radical toxicity," Science, vol. 240, no. 4857, pp. 1302-1309, 1988.

[25] C. M. Creus, R. J. Sueldo, and C. A. Barassi, "Water relations and yield in Azospirillum-inoculated wheat exposed to 
drought in the field," Canadian Journal of Botany, vol. 82, no. 2, pp. 273-281, 2004.

[26] T. Murashige and F. Skoog, "A revised medium for rapid growth and bioassays with tobacco tissue cultures," Physiologia Plantarum, vol. 15, pp. 473-497, 1962.

[27] D. G. He, Y. M. Yang, and K. J. Scott, "A comparison of scutellum callus and epiblast callus induction in wheat: the effect of genotype, embryo age and medium," Plant Science, vol. 57, no. 3, pp. 225-233, 1988.

[28] J. M. Gonzalez, E. Friero, and N. Jouve, "Influence of genotype and culture medium on callus formation and plant regeneration from immature embryos of (Triticum turgidum Desf.) cultivars," Plant Breeding, vol. 120, no. 6, pp. 513-517, 2001.

[29] H. Rashid, R. A. Ghani, Z. Chaudhry, S. M. S. Naqvi, and A. Quraishi, "Effects of media, growth regulators and genotypes on callus induction and regeneration in wheat (Triticum aestivum L.)," Biotechnology, vol. 1, no. 1, pp. 46-54, 2002.

[30] J. Y. Chen, R. Q. Yue, H. X. Xu, X.-J. Chen, and Y. M. Zhang, "Study on plant regeneration of wheat mature embryos under endosperm-supported culture," Agricultural Sciences in China, vol. 5, no. 8, pp. 572-578, 2006.

[31] A. G. Nasircilar, K. Turgut, and K. Fiskin, "Callus induction and plant regeneration from mature embryos of different wheat genotypes," Pakistan Journal of Botany, vol. 38, no. 3, pp. 637-645, 2006.

[32] P. J. Dale and E. Deambrogio, "A comparison of callus induction and plant regeneration from different explants of (Hordeum vulgare L.)," Zeitschrift fur Pflanzenzuchtung, vol. 94, pp. 65-77, 1976.

[33] R. G. Dani, "Biotechnological research of cotton: two decades in soviet retrospection," Advances in Plant Sciences, vol. 5, pp. 433-447, 1992.

[34] A. Chaudhury and R. Qu, "Somatic embryogenesis and plant regeneration of turf-type bermudagrass: effect of 6benzyladenine in callus induction medium," Plant Cell, Tissue and Organ Culture, vol. 60, no. 2, pp. 113-120, 2000.

[35] D. E. Bradle, A. H. Bruneau, and R. Qu, "Effects of cultivar explant treatment, and medium supplements on callus induction and plantlet regeneration in perennial ryegrass," International Turfgrass Society Research Journal, vol. 9, pp. 152-156, 2001.

[36] D. G. He, G. Tanner, and K. J. Scott, "Somatic embryogenesis and morphogenesis in callus derived from the epiblast of immature embryos of wheat (Triticum aestivum)," Plant Science, vol. 45, no. 2, pp. 119-124, 1986.

[37] P. Bregitzer, L. S. Dahleen, and R. D. Campbell, "Enhancement of plant regeneration from embryogenic callus of commercial barley cultivars," Plant Cell Reports, vol. 17, no. 12, pp. 941945, 1998.

[38] A. M. R. Balli, B. G. Rossnagel, and K. K. Kartha, "Evaluation of 10 Canadian barley (Hordeum vulgare L.), Cultivars for tissue culture response," Canadian Journal of Plant Science, vol. 73, pp. 171-174, 1993.

[39] S. A. El-Meleigy, M. F. Gabr, F. H. Mohamed, and M. A. Ismail, "Responses to $\mathrm{NaCl}$ salinity of tomato cultivated and breeding lines differing in salt tolerance in callus cultures," International Journal of Agriculture \& Biology, vol. 6, no. 1, pp. 19-26, 2004.

[40] A. M. Rus, M. Panoff, F. Perez-Alfocea, and M. C. Bolarin, "NaCl responses in tomato calli and whole plants," Journal of Plant Physiology, vol. 155, no. 6, pp. 727-733, 1999.

[41] A. M. Rus, S. Rios, E. Olmos, A. Santa-Cruz, and M. C. Bolarin, "Long-term culture modifies the salt responses of callus lines of salt-tolerant and salt-sensitive tomato species," Journal of Plant Physiology, vol. 157, no. 4, pp. 413-420, 2000.
[42] D. M. Chen, F. J. Keiper, and L. F. De Filippis, "Physiological changes companying the induction of salt tolerance in Eucalyptus microcroys shoots in tissue culture," Journal of Plant Physiology, vol. 152, pp. 555-563, 1998.

[43] T. Abebe, A. C. Guenzi, B. Martin, and J. C. Cushman, "Tolerance of mannitol-accumulating transgenic wheat to water stress and salinity," Plant Physiology, vol. 131, no. 4, pp. 1748-1755, 2003.

[44] L. Benderradji, F. Brini, S. Ben Amar et al., "Sodium transport in seedlings of two bread wheat (Triticum aestivum L.) genotypes differing in their tolerance to salt stress," Australian Journal of Crop Sciences, vol. 5, no. 3, pp. 233-241, 2011.

[45] S. Lutts, M. Almansouri, and J. M. Kinet, "Salinity and water stress have contrasting effects on the relationship between growth and cell viability during and after stress exposure in durum wheat callus," Plant Science, vol. 167, no. 1, pp. 9-18, 2004.

[46] R. A. Richards, "Defining selection criteria to improve yield under drought," Plant Growth Regulation, vol. 20, no. 2, pp. 157-166, 1996.

[47] H. J. Bohnert, R. G. Jensen, T. J. Flowers, and A. R. Yeo, "Metabolic engineering for increased salt tolerance-the next step," Australian Journal of Plant Physiology, vol. 23, no. 5, pp. 661-667, 1996.

[48] I. Winicov, "Characterization of rice (Oryza sativa L.) plants regenerated from salt-tolerant cell lines," Plant Science, vol. 113, no. 1, pp. 105-111, 1996. 


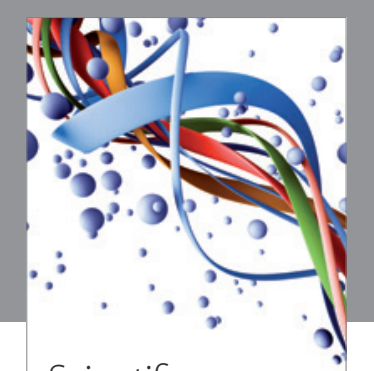

Scientifica
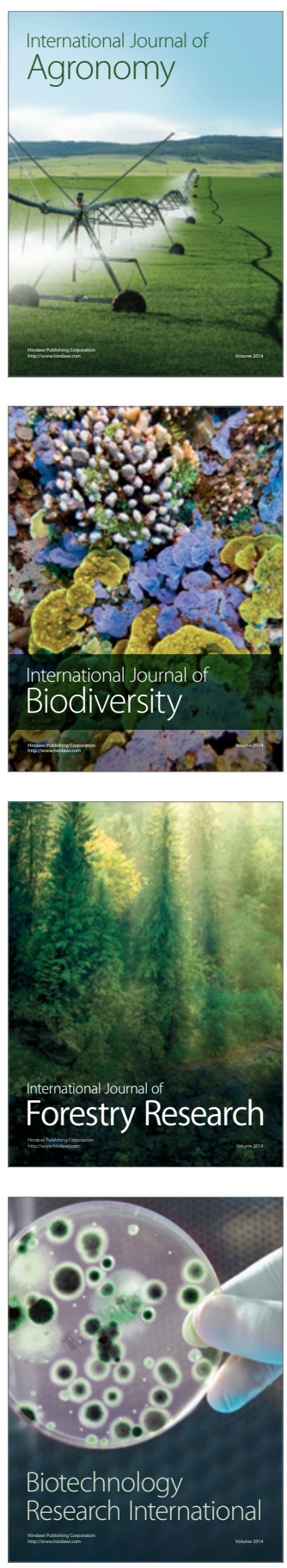
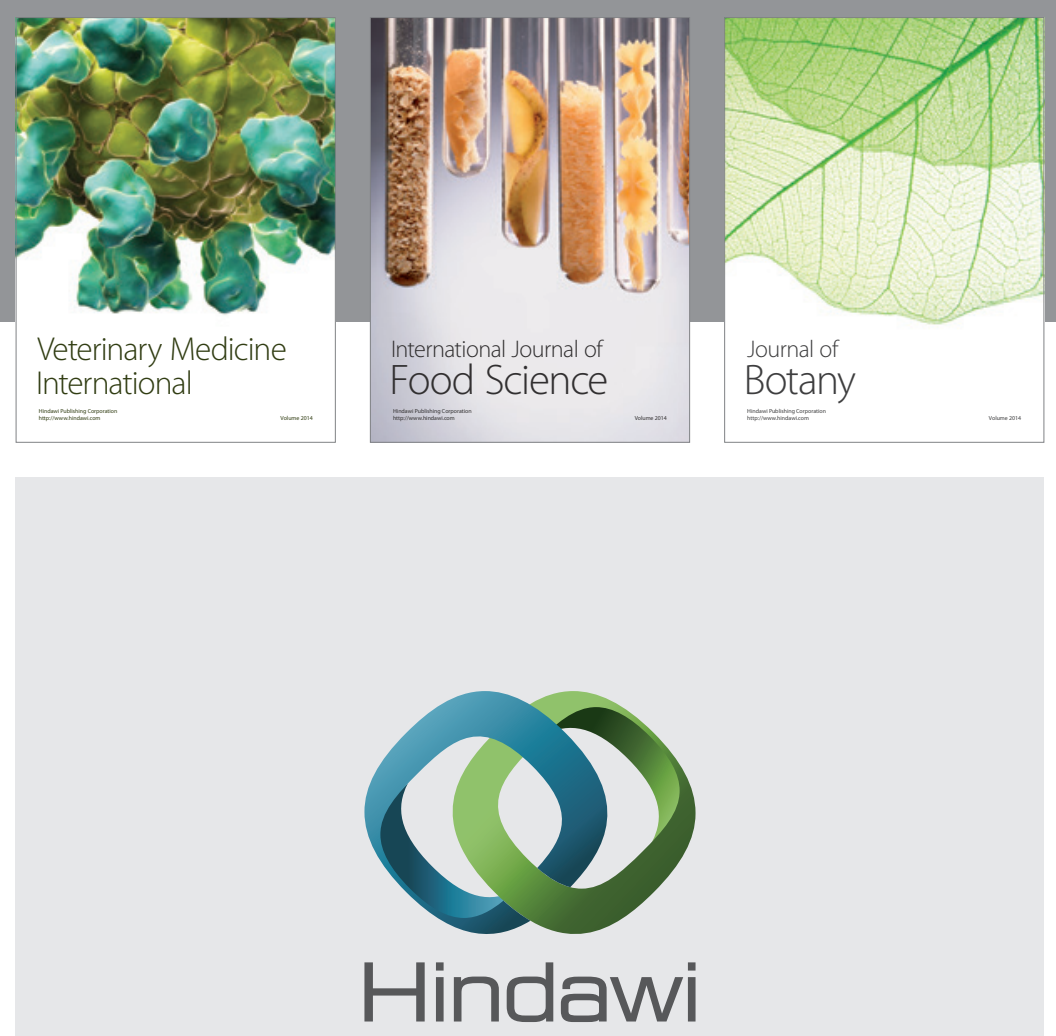

Submit your manuscripts at

http://www.hindawi.com
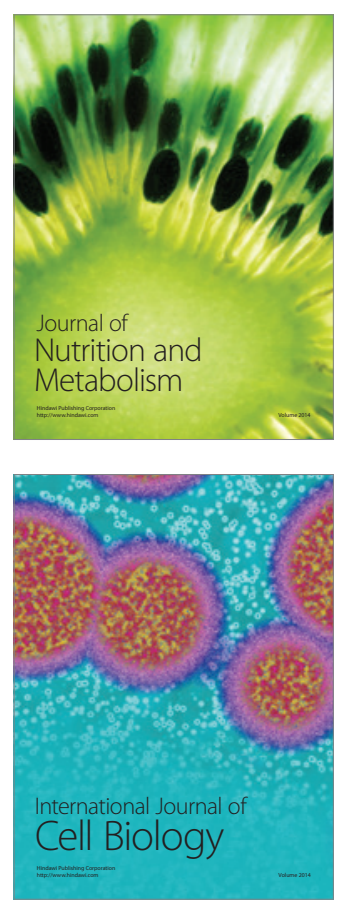
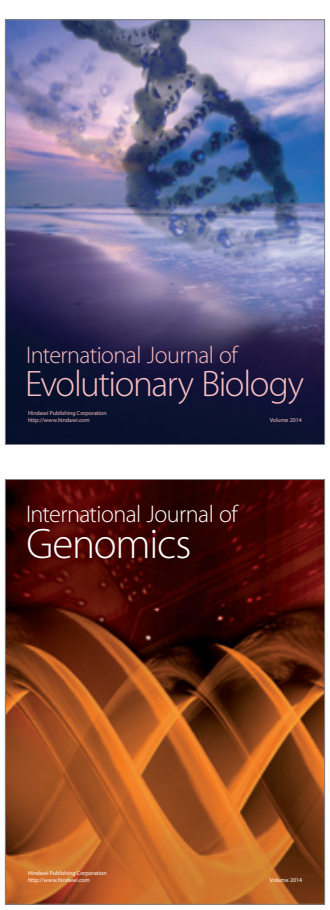
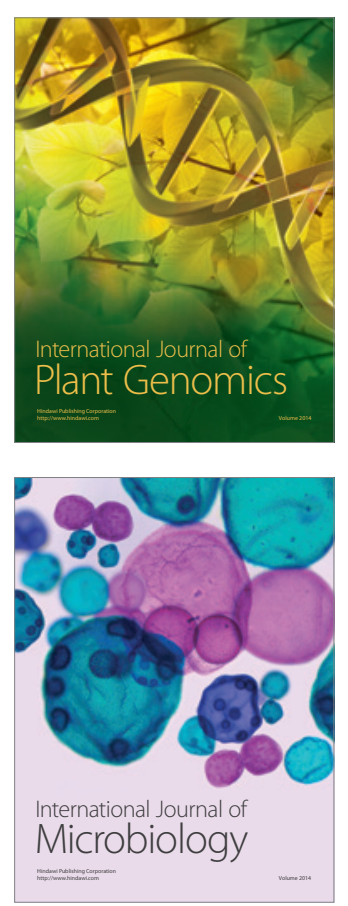

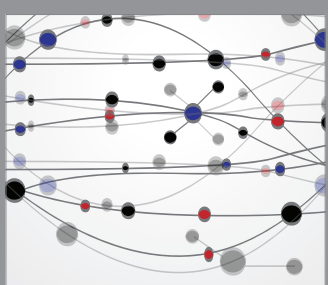

The Scientific World Journal
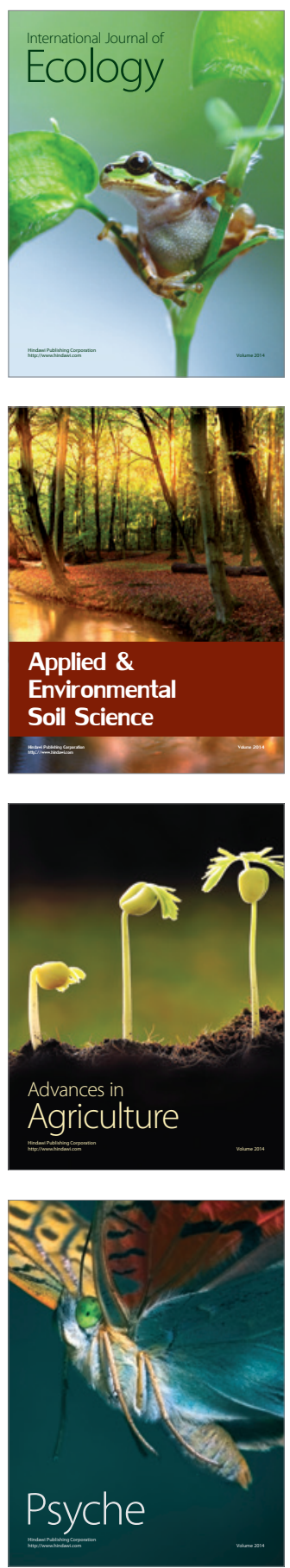